\title{
Assessment of relative environmental risk from logyard run-off in British Columbia
}

\author{
by Julie L. Orban ${ }^{1}$, Robert A. Kozak ${ }^{2}$, Roy C. Sidle ${ }^{3}$ and Sheldon J.B. Duff ${ }^{4}$
}

Run-off is generated at logyards at sawmills and dryland sorts when mobile water interacts with woody debris. Logyard run-off can contain a range of constituents with the potential to have an adverse impact on the receiving environment. Many geoclimatic, operational and physical factors contribute to the volume and characteristics of run-off, and a management tool to predict relative environmental risk from different sites would be of value. In this study, we attempted to develop such a tool. A survey was devised and distributed to logyard operators in British Columbia. The survey provided information on site characteristics, volumes and types of wood processed, operational practices, the incidence of run-off, run-off treatment practices, as well as the ultimate receiving environment. Qualitative and quantitative data from the survey were subjected to statistical analyses to: (1) determine the factors that contributed to risk; (2) assign relative risk ratings to each site; and (3) rank facilities according to their potential to impact the receiving environment. Multidiscriminant analysis was used to determine which factors were correlated to environmental risk posed by run-off. Eighty-nine percent (64/72) of the facilities had visible run-off. Sixty-six percent (42/64) of the facilities fell into the high risk category with the remaining 34\% (22/64) being low risk. In order of importance, volume of wood stored onsite (largest contribution), frequency of run-off events and colour intensity of run-off (smallest contribution) were factors that significantly contributed to risk and were correlated positively. The methods employed in this study could be applied as management tools to identify sites for further assessment and evaluate the need for remediation.

Keywords: wood leachate, run-off, logyard, dryland sort, environmental impact, toxic, remediation

Les déversements sont créés dans les cours à bois des scieries et dans les cours de triage à sec lorsque l'eau de ruissellement entre en contact avec les débris ligneux. Les déversements des cours à bois peuvent contenir une variété d'éléments qui peuvent potentiellement avoir un impact négatif sur le milieu adjacent. Plusieurs facteurs géoclimatiques, opérationnels et physiques contribuent au niveau du volume et des caractéristiques des déversements, et un outil de gestion pour prédire le risque environnemental relatif des différents sites pourrait être utile. Au cours de ce projet, nous avons essayé de développer un tel outil. Un sondage a été élaboré et distribué aux opérateurs de cours à bois de la Colombie-Britannique. Le sondage a fourni de l'information sur les caractéristiques du site, sur les volumes et les types de bois manipulés, sur les pratiques opérationnelles, sur l'incidence des déversements, sur les méthodes de traitement des déversements, ainsi que sur l'environnement connexe. Les données qualitatives et quantitatives du sondage ont été soumises à des analyses statistiques afin: (1) de déterminer les facteurs qui contribuaient au risque; (2) à assigner une cote de risque à chaque site; et (3) à classer les sites selon leur potentiel à créer un impact au niveau de l'environnement connexe. Une analyse multidiscrinatoire a été utilisée pour déterminer quels facteurs étaient corrélés au risque environnemental créé par les déversements. Quatre-vingt-neuf pour-cent (64/72) des sites avaient des signes visibles de déversement. Soixante-six pour-cent (42/64) des sites se classaient dans la catégorie à haut risque tandis que les autres 34 \% (22/64) se classaient dans la catégorie à faible risque. En fonction de l'importance, le volume entreposé sur le site (la plus importante contribution) la fréquence des déversements et l'intensité de la couleur des déversements (la plus faible contribution) constituaient les facteurs qui ont contribué significativement au risque et ont été corrélés positivement. Les méthodes utilisées dans cette étude pourraient être utilisées en tant qu'outils de gestion pour identifier les sites nécessitant une évaluation plus poussée et pour évaluer les besoins en terme de remédiation.

Mots-clés: percolation ligneuse, déversement, cours à bois, cours de triage à sec, impact environnemental, remédiation

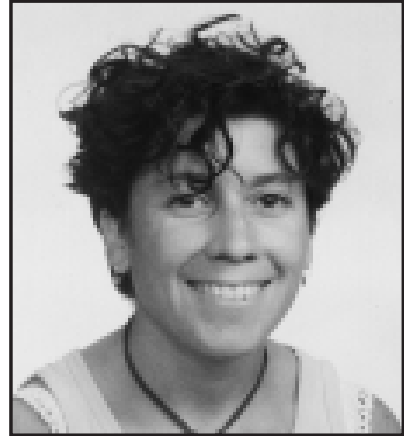

Julie L. Orban

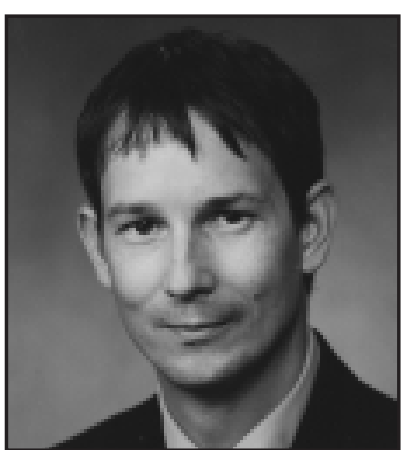

Robert A. Kozak

${ }^{1}$ Department of Forest Resources Management, University of British Columbia, 2424 Main Mall, Vancouver, B.C. V6T 1Z4. Current address: Slocan Forest Products Ltd., 705 Delany, Slocan, B.C. V0G 2C0. E-mail: jorban@netidea.com

${ }^{2}$ Department of Wood Science, Faculty of Forestry, University of British Columbia, \#4041-2424 Main Mall, Vancouver, B.C. V6T 1Z4. E-mail: rkozak@interchange.ubc.ca

${ }^{3}$ Department of Geography, National University of Singapore, 1 Arts Link, Kent Ridge, Singapore, 117570. E-mail: geosrc@nus.edu.sg

${ }^{4}$ Department of Chemical and Biological Engineering, University of British Columbia, \#305-2216 Main Mall, Vancouver, B.C. V6T 1Z4. E-mail: sduff@chml.ubc.ca To whom correspondence should be addressed.

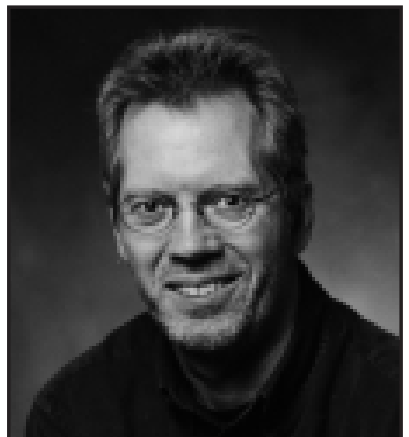

Roy C. Sidle

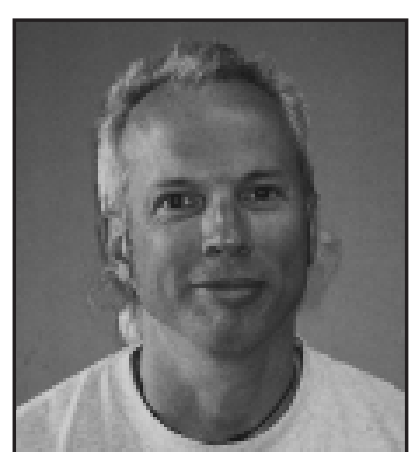

Sheldon J.B. Duff

\section{Introduction}

The primary function of logyards at sawmills and dryland sorts is to receive cut logs, sort them by species, size and quality, and facilitate their transport to an appropriate processor. These facilities can range from less than 1 ha to over 100 ha in size and can process wood volumes ranging from $1000 \mathrm{~m}^{3}$ to over $1000000 \mathrm{~m}^{3}$ annually. Large quantities of woody debris, from $3-6 \%$ by volume of the processed wood, are generated at logyards (McWilliams 1992). 
Water is introduced to logyards in many ways, including rainfall, snow melt, carry over from logs transported in water, equipment cleaning and sprinkling of log decks and yard surfaces to prevent fire, dust or deterioration. Potential sources of water pollutants at logyards include: woody debris (especially bark); stored logs; log and liquid loading areas; rollout, sorting, scaling and cutting areas; truck, rail, ship, stacker and loader access areas; debarker, hog bin, and conveyer areas; ash piles and other solid wastes; log trucks, stackers, loaders, forklifts and other equipment; maintenance shop and parking areas; cleaning areas for vehicles, parts and equipment; metal salvage areas; pesticides used for log preservation or surface protection; contaminated soil; and storage and handling areas for hydraulic oils, lubricants, fuel, paints, liquid wastes and other liquid materials and herbicides (NCASI 1992, WDOE 1995). Contact between water and these various sources of pollutants can generate a run-off or leachate that is contaminated with a range of constituents (NCASI 1992, AEP 1996, AFPA 1999a, Samis et al., 1999). The volume, characteristics and environmental impact of run-off from a particular site are dictated by several factors, including species and volume of wood processed, climatic considerations (e.g., precipitation amount, frequency and duration), site characteristics (e.g., surface cover, proximity to water), and practices (e.g., sprinkling of wood, equipment cleaning practices, run-off control and treatment measures).

Three general categories of water quality concerns related to storm-water run-off at logyards have been identified: (1) wood and bark-derived organics, particulates and foam; (2) sediment from logyard erosion; and (3) greases and oils from logyard vehicles and associated mill machinery (NCASI 1992, AEP 1996). Of the organics extracted from softwood, tannins, lignins, phenolics, tropolones and resin acids are of greatest concern as contributors to run-off toxicity (Samis et al. 1999). Schuytema and Shankland (1976) observed that leachate from Ponderosa pine (Pinus ponderosa) logs contained more organics than leachate from Douglas-fir (Pseudotsuga menziesii) logs. Pease (1974) ranked the following species, in descending order, by leachate generation rates: Red cedar (Thuja plicata) > Yellow cedar (Chamaecyparis nootkatensis) > Western hemlock (Tsuga heterophylla) $>$ Sitka spruce (Picea sitchensis). It has been reported that Norway spruce (Picea excel$s a$ ) sprinkling water was more concentrated and had higher Microtox toxicity than that from Scotch pine (Pinus sylvestris) (Borga et al. 1996a). While hardwoods are considered to produce less contaminated leachates, aspen (Populus tremuloides) has the potential to produce amber to black leachate containing sugars, sap, cell cytoplasm and a suite of phenolic compounds. Measured by composite parameters, in comparison to leachates from regional softwoods, aspen leachate displayed a low $\mathrm{pH}$ (4.0), high biochemical oxygen demand (BOD) (>2600 mg/L), high conductivity (1140 dS/cm), high phenols $(30 \mathrm{mg} / \mathrm{L})$, high organic carbon $(2480 \mathrm{mg} / \mathrm{L})$ and high organic nitrogen $(13 \mathrm{mg} / \mathrm{L})$. As well, chipped wood leached much faster than logs due to the higher surface area of chips (Taylor et al. 1996).

Numerous parameters have been used to characterize logyard run-off and can be classified based on the frequency with which they were assayed (Schaumberg and Williamson 1975, NCASI 1992, WDOE 1995, AEP 1996, Taylor et al. 1996, AFPA 1999a, Samis et al. 1999). The highest frequency class includes five-day biochemical oxygen demand $\left(\mathrm{BOD}_{5}\right)$, chemical oxygen demand (COD), dissolved oxygen (DO), $\mathrm{pH}$ and total suspended solids (TSS). The moderate frequency class includes colour, resin acids, fatty acids, nutrients (nitrate, nitrite, total kjedahl nitrogen and total phosphate), oil and grease (O \& G), phenols, tannins and lignins (TL), total organic carbon (TOC) and toxicity testing (Rainbow trout/Oncorhynchus mykiss, Ceriodaphnia and Microtox). The lowest frequency class includes conductivity, heavy metals (e.g., lead and zinc), fecal coliforms, pesticides, settleable solids (SS), temperature and total volatile solids. Bioassay testing should accompany chemical analyses as bioassays integrate the toxic effects of various constituents and are reliable indicators of leachate strength (Samis et al. 1999). In an effort to capture many of the constituents of concern using a reasonable suite of tests, the following candidate parameter list has been proposed for monitoring: resin acids, fatty acids, phenols, $\mathrm{pH}, \mathrm{DO}, \mathrm{O} \& \mathrm{G}$, COD, BOD 5 , TL, and TSS (AFPA 1999a). As well, Brent and Herricks (1999) recently outlined a method for assessing the toxicity of episodic wet weather events.

Considerable effort has been expended on the development and implementation of best management practices (BMPs) to minimize the impact of logyard run-off on the receiving environment. Some of these BMPs include eliminating wood residue piles, cleaning the logyard deck of woody materials and grading the logyard decks to minimize areas where water can pool and contact woody debris (e.g., Toews and Brownlee 1981, WDOE 1990, 1995 and 2000, USEPA 1995, DOE and FRAP 1996, AFPA 1999b). Despite implementation of these practices, some sites still produce run-off that may have a deleterious effect on the receiving environment. A range of run-off treatment technologies has been proposed, including biological treatment (e.g., aeration lagoons, activated-sludge systems and artificial wetlands) and physical and chemical treatment (e.g., aeration, carbon adsorption, chemical oxidation using ozone, calcium hypochlorite, hydrogen peroxide and potassium permanganate, chelation, coagulation, ion exchange, neutralization, precipitation and reverse osmosis) (Samis et al. 1999). Borga et al. (1996b) demonstrated that levels of contaminants in recycled logyard sprinkler water were stabilized by biological treatment.

This study had two goals. First, using survey data, an effort was made to determine the scale of the logyard run-off issue in British Columbia. Second, we sought to develop an initial screening method to classify logyards into those that posed a relatively high or low risk to the receiving environment. Such a methodology may be useful as a management tool to identify sites for further assessment and evaluate the need for remediation.

\section{Materials and Methods}

\section{Survey design and distribution}

The study made use of a survey intended for site managers of logyards at sawmills and dryland sorts throughout British Columbia. The Council of Forest Industries (COFI) administered and distributed the survey. Survey responses were confidential and individual facilities remained anonymous.

The survey sought information regarding the general operation and setting (e.g., volumes and species of wood stored, methods of ground cleaning, climatic conditions, proximity to watercourses) of the facilities. It was seven pages in length 


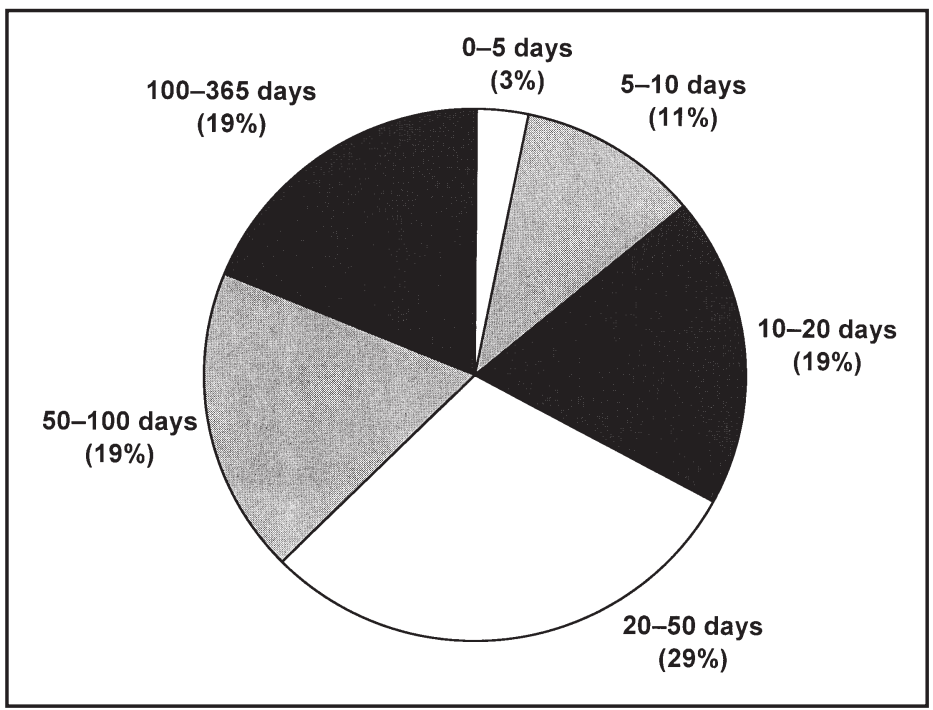

Fig. 1. Distribution of the frequency of logyard run-off (days per year).

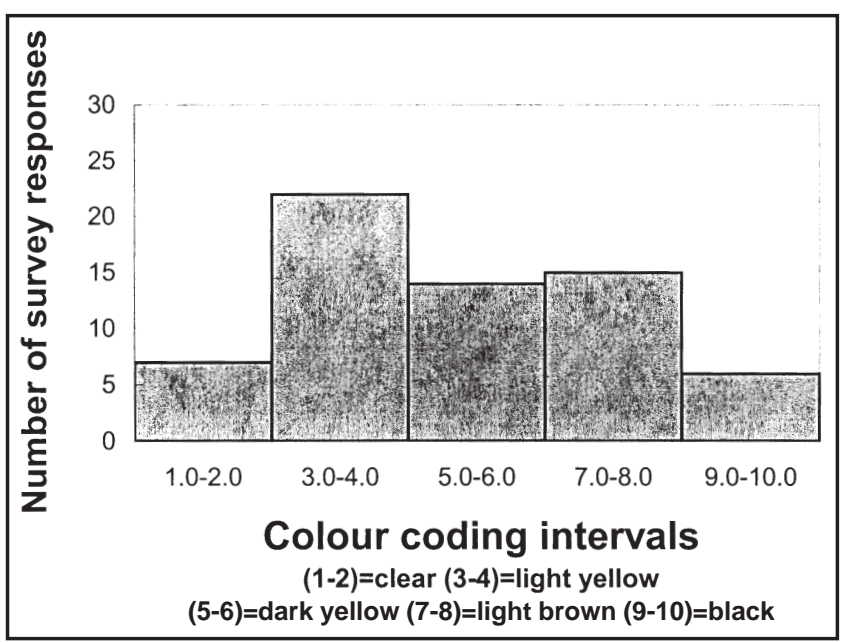

Fig. 2. Distribution of run-off colour at British Columbia logyards.

and posed 37 questions within six sections. The sections were: (1) General Company Information, (2) Run-off Information, (3) Operation Information, (4) Site Information, (5) Precipitation / Water Input Information, and (6) Comments. The estimated time required to complete the survey was $20 \mathrm{~min}$ utes.

The data collected in the survey identified some of the onsite factors (i.e. independent variables) responsible for the generation and environmental impact of logyard run-off. A more detailed survey including quantitative information about the receiving environment would likely reduce response rates. For a preliminary estimate of risk, an anticipated higher response rate at the expense of data richness was deemed appropriate.

\section{Data management and analysis}

The main objectives of the survey were to assess the scope of the run-off issue associated with logyards at sawmills and dryland sorts in $\mathrm{BC}$, and to develop a preliminary mechanism for predicting relative risk levels. For analytical purposes, risk was defined as the relative potential of a detrimental effect occurring to the receiving environment and the organisms that live within the receiving environment. The receiving environment was defined as the natural area beyond the confines of the logyard that included surface water bodies (e.g., lakes, rivers, streams, and oceans) and ground cover (e.g., soil, vegetation). To assess risk, two methods were employed, a subjective classification and a predictive classification using multidiscriminant analysis (MDA).

\section{Subjective (qualitative) analysis}

Subjective screening of survey data identified the following nine survey questions as critical factors that contributed to environmental risk: (1) On how many days per year does run-off occur? (2) Where does the run-off terminate? (3) What is the colour of the run-off? (4) Is the collected run-off treated? (5) How many seasons per year does the facility operate? (6) What volume of wood is handled at the facility annually? (7) What is the total area of the facility? (8) Is water applied to control dust or for fire prevention? and (9) How frequently is the logyard cleaned? The responses to each of these nine questions were divided into high and low categories, receiving a coded score of 2 or 1 , respectively. The coded scores for each of the nine questions were added together to produce a total score for the logyard, and the median of logyard scores was used as a cut-off between low and high risk sites. It should be noted that certain accuracy limitations exist from personal bias and human oversight when applying subjective classifications.

\section{Multidiscrimant analysis}

The subjective classification data became the input for the second classification tool, multidiscriminant analysis (MDA). While the MDA was used for predictive purposes (i.e., is a site low or high risk?), due to the subjective nature of the data at hand, the primary use of this tool was to weight each of the factors (independent variables) according to their relative contribution to risk. MDA used the responses from questions 1,3, and 5. Data from question 1 was converted from a categorical response to interval data by using class midpoints 


\begin{tabular}{|c|c|c|c|}
\hline $\begin{array}{l}\text { Survey } \\
\text { Q\# }\end{array}$ & Question/Factor & $\begin{array}{l}\text { Low risk response } \\
\text { numerical code }=1\end{array}$ & $\begin{array}{l}\text { High risk response } \\
\text { numerical code }=2\end{array}$ \\
\hline (1) & $\begin{array}{l}\text { runoff frequency } \\
\text { (days per year) }\end{array}$ & $\begin{array}{l}\text { not often } \\
(<5 \text { days/year, } \\
5-10 \text { days/year or } \\
\text { 10-20 days/year) }\end{array}$ & $\begin{array}{l}\text { often } \\
\text { (20-50 days/year, } \\
50-100 \text { days/year or } \\
>100 \text { days/year) }\end{array}$ \\
\hline (2) & $\begin{array}{l}\text { where runoff } \\
\text { terminates }\end{array}$ & $\begin{array}{l}\text { not in water } \\
\text { (e.g., gully, ditch, ground) }\end{array}$ & $\begin{array}{l}\text { in water } \\
\text { (e.g., river, stream, wetland, ocean) }\end{array}$ \\
\hline (3) & $\begin{array}{l}\text { runoff colour } \\
\# \text { s } 1-10 \text { : } \\
(\# 1=\text { clear }-\# 10=\text { black })\end{array}$ & $\begin{array}{l}1-5.4 \\
\text { (on } 1-10 \text { interval scale) }\end{array}$ & $\begin{array}{l}5.5-10 \\
\text { (on } 1-10 \text { interval scale) }\end{array}$ \\
\hline (4) & runoff treatment applied & yes & no \\
\hline (5) & runoff frequency (seasons per year) & $\begin{array}{l}\text { not often } \\
\text { ( } 1 / 4 \text { or } 2 / 4 \text { seasons/year) }\end{array}$ & $\begin{array}{l}\text { often } \\
\text { ( } 3 / 4 \text { or } 4 / 4 \text { seasons/year) }\end{array}$ \\
\hline (6) & $\begin{array}{l}\text { volume of wood } \\
\text { handled at the facility ( } \mathrm{m}^{3} / \text { year) }\end{array}$ & $\begin{array}{l}<329500 \mathrm{~m}^{3} \\
\text { (below median value) }\end{array}$ & $\begin{array}{l}>329000 \mathrm{~m}^{3} \\
\text { (above median value) }\end{array}$ \\
\hline (7) & facility area (ha) & $\begin{array}{l}<5.4 \text { ha } \\
\text { (below median value) }\end{array}$ & $\begin{array}{l}>5.4 \text { ha } \\
\text { (above median value) }\end{array}$ \\
\hline$(8)$ & $\begin{array}{l}\text { water application for } \\
\text { dust control and/or fire prevention }\end{array}$ & no & yes \\
\hline (9) & ground cleaning frequency & $\begin{array}{l}\text { not often } \\
\text { (e.g., never, monthly, annually, } \\
\text { as required, summer continuously) }\end{array}$ & $\begin{array}{l}\text { often } \\
\text { (e.g., continuously, daily, weekly) }\end{array}$ \\
\hline
\end{tabular}

\begin{tabular}{|c|c|c|c|c|}
\hline $\begin{array}{l}\text { SITE ID \# } \\
\text { (Survey Response) }\end{array}$ & $\begin{array}{c}\text { RANKINGS } \\
\text { (\#1 rank = highest risk site) }\end{array}$ & $\begin{array}{l}\text { Wood Volume Processed } \\
\left(\mathrm{m}^{3} / \mathrm{yr}\right)\end{array}$ & $\begin{array}{c}\text { Coded Frequency of Run-off } \\
\text { (days/year) }\end{array}$ & $\begin{array}{l}\text { Colour of Run-off } \\
\text { (\#1-10 scale) }\end{array}$ \\
\hline 3 & 1 & 1300000 & 232.5 & 7 \\
\hline 4 & 2 & 1200000 & 232.5 & 7 \\
\hline 72 & 3 & 636000 & 232.5 & 10 \\
\hline 73 & 4 & 670000 & 232.5 & 7 \\
\hline 56 & 5 & 350000 & 232.5 & 9 \\
\hline $\begin{array}{l}\text { SITE ID \# } \\
\text { (Survey Response) }\end{array}$ & $\begin{array}{c}\text { RANKINGS } \\
\text { (\#63 rank = lowest risk site) }\end{array}$ & $\begin{array}{l}\text { Wood Volume Processed } \\
\qquad\left(\mathrm{m}^{3} / \mathrm{yr}\right)\end{array}$ & $\begin{array}{c}\text { Coded Frequency of Run-off } \\
\text { (days/year) }\end{array}$ & $\begin{array}{l}\text { Colour of Run-off } \\
\text { (\#1-10 scale) }\end{array}$ \\
\hline 26 & 58 & 150000 & 15 & 4 \\
\hline 60 & 60 & 300000 & 15 & 2 \\
\hline 13 & 61 & 165000 & 15 & 3 \\
\hline 33 & 62 & 40000 & 2.5 & 4 \\
\hline 34 & 63 & 8000 & 7.5 & 4 \\
\hline
\end{tabular}

and assuming a normal distribution. The MDA identified and weighted statistically significant factors in predicting the dependent categorical variable (high or low risk). It also served to rank sites within a given high or low risk category. The lower the model output values, the higher the anticipated relative environmental risk. MDA analysis was carried out using Statistica statistical software (Release 5).

\section{Results and Discussion}

\section{Summary of run-off at British Columbia logyards}

In total, 74 completed surveys were received. One survey was eliminated because it was a pulpmill and another was eliminated because it was a duplicate. Eight reported that a visible run-off did not occur. We therefore used 64 out of 72 (89\%) surveys for analytical purposes. The total number of surveys distributed is unknown because COFI distributed surveys to corporate head offices who then apportioned an untracked number of copies to their regional offices. The survey response rate and non-response bias are therefore unknown.

Survey results indicated that run-off is a common occurrence, present at $89 \%$ of the surveyed logyards (including dryland sorts) throughout British Columbia. The majority of sites reported a visible run-off occurring 20 to 50 days per year (Fig. 1). Run-off usually appeared in winter and spring and coincided with rain and snowmelt, and water application for dust and fire control. In most cases, run-off terminated in the ocean $(31.6 \%)$ or into the ground $(30.5 \%)$. The average colour of run-off, determined subjectively by respondents, was dark yellow (Fig. 2). While colour may not correlate well with run-off quality parameters such as BOD or acute toxicity, it could be assessed by non-technical staff and provided a general gauge of run-off strength. Chemical analyses were not commonly performed on run-off. Approximately half of the sites (35/64 sites) collected run-off and most of these sites (29/35 sites) treated the run-off (e.g., using sediment traps). There was no correlation between run-off treatment and predicted relative risk. The average facility was 21 years old and most operated throughout the entire year. Fir, hemlock and pine were the most common species handled at the logyards. Chipping and hogging were not ordinarily practised onsite. The aver- 


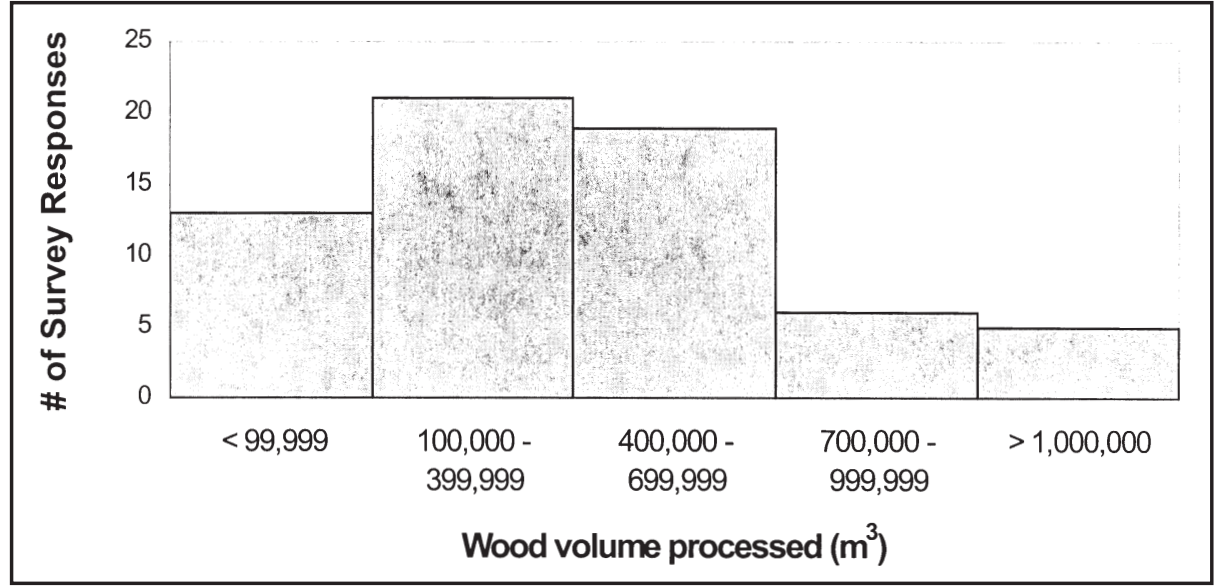

Fig. 3. Annual volume of wood processed at British Columbia logyards. age and median volumes of wood handled at these sites were $412750 \mathrm{~m}^{3} /$ year and $329500 \mathrm{~m}^{3} /$ year, respectively (Fig. 3). The average and median sizes of the facilities were 17.4 ha and 5.4 ha, respectively. Gravel surfaces were most common (at $36.5 \%$ of sites), although dirt (22.1\%) and asphalt (19.2\%) surfaces were also common. Surfaces were generally cleaned on a continuous basis.

\section{Qualitative screening of survey data}

Coded responses to nine questions (Table 1) generated site totals ranging from 11-18. Sites that scored in the lower half of this range (scores between 11 and 14) were classified as low risk sites and those in the upper half (between 15 and 18 ) as high risk sites. Based on this qualitative ranking, $34 \%$ $(22 / 64)$ were assigned a low relative risk rating, and the remainder ( $66 \%$ or $42 / 64)$ were assigned a high relative risk ranking.

\section{Multidiscriminant analysis}

Volume of wood stored onsite (VOL), frequency of run-off events (FREQ) and colour (COL) of run-off were significant factors identified by MDA in predicting risk posed by run-off. Based on these factors, a model was produced:

$$
\mathrm{Y}=2.47-0.000002 \mathrm{VOL}-0.0069 \mathrm{FREQ}-0.191 \mathrm{COL}
$$

where "Y" is the predicted relative risk, "VOL" is volume of wood handled at the facility ( $\mathrm{m}^{3} /$ year), "FREQ" is frequency of run-off (days/year) and "COL" is a numerically coded colour of the run-off (i.e., $1=$ clear to $10=$ black). The coefficients of this predictive model were subsequently standardized in order to determine the degree to which each variable contributes to risk. Upon transformation, the model with the standardized coefficients was:

$$
\mathrm{Y}=2.47-0.704 \mathrm{VOL}-0.521 \mathrm{FREQ}-0.436 \mathrm{COL}
$$

All factors were significant (at $\alpha=0.1$ ). The lower the numerical output, the higher the risk and more harmful the environmental impact posed by the run-off. The standardized coefficients showed that the volume of wood processed had the most significant influence on determining risk level. Wood volume processed was 1.3 times more influential in determining risk than frequency and 1.6 times more influential than colour. Frequency was 1.1 times more influential than colour.

\section{Predicting relative risk}

The MDA model assigned a numerical value between -3.07 and 1.64 to the relative risk. Comparing the MDA output to the qualitative rankings gave a cut-off $\mathrm{Y}$ value of 0.80 ; low risk sites scored above this value, while high risk sites fell below it. Within the high and low risk categories identified through subjective analysis, MDA provided a site ranking. For example, the relatively high risk sites were ranked from 1 (most risk) to 42 . The characteristics of the five highest and five lowest ranked sites are given in Table 2.

The primary purpose for using MDA was to identify and weight risk factors. Although MDA models can predict risk groups, this method is not recommended for predicting risk as the hitrate, when referenced to the subjectively classified risk ratings, was only $80 \%$. We recommend predicting risk groups by utilizing both the subjective risk ratings and the MDA model outputs.

A limitation to our methods arose from a compounding and circular error situation. Error-laden data associated with personal bias and human oversight from subjective assignments were used by the model. The output of the model was then classified using the same subjective data to determine a final risk rating. As well, for MDA to perform optimally, data should be normally distributed. Volume of wood, frequency of runoff and colour of run-off were the three data sets used in the MDA. Colour was normally distributed while frequency and volume were not. Therefore, error resulted by performing MDA on the two non-normally distributed data sets, and some caution should be exercised in interpreting these results.

Other sites could be incorporated into this provincial ranking by answering the three survey questions and running the numerically coded responses through the model, adding their corresponding output values to the database and re-applying the ranking function.

\section{Conclusions}

The volume of wood processed, frequency of run-off events and colour intensity of run-off were significantly and positively correlated to the relative environmental risk posed by logyard run-off. Sites fell into the high risk category if the volume of wood stored processed on site was greater than 329000 $\mathrm{m}^{3} /$ year, the run-off occurred more than 20 days/year and the 
colour of run-off was dark yellow. Methodology developed for this study may provide a useful preliminary determination of relative risk to the receiving environment from logyard runoff. Based on this analysis, options such as run-off analysis, run-off management or treatment may be evaluated.

Further, the results of this study provide information for subsequent field-based studies. Future work should be conducted to gather onsite water quality data in order to validate the effectiveness of this method as a tool for predicting risk at logyards and to improve the predictive power of the tool by including additional quantitative information.

\section{Acknowledgements}

The authors gratefully acknowledge the technical input of L. Lavkulich, K. Hall and A. Fikart (Institute for Resources and Environment, UBC), C. Breuil (Wood Science Department, UBC) and WestFraser Timber, Weyerhaeuser, Canfor, BC Hydro and COFI for their survey design, administration and distribution. Thanks are due to the survey respondents for their participation. The research was funded by Grad Ilic of the B.C. Hydro Water and Wastewater Centre. We are grateful, as well, to A. Ferguson (Slocan Forest Products, Slocan Division) and R. D'Eon (Forest Sciences Department, UBC) who reviewed previous drafts, and to two anonymous reviewers who provided valuable comments.

\section{References}

AEP. 1996. Assessment of logyard run-off in Alberta - preliminary evaluation. Alberta Environmental Protection. Edmonton, AB. AFPA. 1999a. Characterization of surface water run-off from logyard and dryland sort sites in Alberta. Alberta Forest Products Association. Edmonton, AB.

AFPA. 1999b. Evaluation and control of environmental effects from logyard sites in Alberta. Alberta Forest Products Association Edmonton, AB.

Borga, P., T. Elowson and K. Liukko. 1996a. Environmental loads from water-sprinkled softwood timber -1 . Characteristics of an open and a recycling watering system. Environmental Toxicology and Chemistry 15: 856-867.

Borga, P., T. Elowson and K. Liukko. 1996b. Environmental loads from water-sprinkled softwood timber -2 . Influence of tree species and water characteristics on wastewater discharges. Environmental Toxicology and Chemistry 15: 1445-1454.

Brent, R.N. and E.E. Herricks. 1999. A method for the toxicity assessment of wet weather events. Water Research. 33: 2255-2264.

DOE and FRAP. 1996. Guidelines on storage, use and disposal of wood residue for the protection of fish and fish habitat in British Columbia. Department of environment and Fraser River action plan. DOE/DFO Report 95-18. 28 p.

McWilliams, J. 1992. Logyard and dryland sort debris: The ultimate solution. Canadian Forest Industries Journal. Jan/Feb 1992: 16-18. NCASI. 1992. Storm water from log storage sites: A literature review and case study. National Council of the Paper Industry for Air and Stream Improvement, Inc. New York, USA. NCASI Technical Bulletin: No. 637.

Pease, B.C. 1974. Effects of log dumping and rafting on the marine environment of Southeast Alaska. Fisheries Research Institute, USDA Forest Service General, University of Washington, Seattle. Technical Report. Pub \#: PNW-22. Seattle, WA, USA. 58 p.

Samis, S.C., S.D. Liu, B.G. Wernick and M.D. Nassichuk. 1999. Mitigation of fisheries impacts from the use and disposal of wood residue in British Columbia and the Yukon. Canadian Technical Report of Fisheries and Aquatic Sciences 2296. Fisheries and Oceans Canada and Environment Canada. 91 p.

Schaumburg, F.D. and K. J. Williamson. 1975. Pre-proposal for California forest protective association. Oregon State University, Department of Civil Engineering. Corvalis, OR, USA.

Schuytema, G.S., and R.D. Shankland. 1976. Effects of log handling and storage on water quality. US Environmental Protection Agency. EPS-600/2-76-262.

Taylor, B.T., J.S. Goudey and N. B. Carmichael. 1996. Toxicity of aspen wood leachate to aquatic life: Laboratory studies. Environmental Toxicology and Chemistry 15: 150-159.

Toews, D.A.A. and M.J. Brownlee. 1981. A handbook for fish habitat protection on forest lands in British Columbia. Department of Fisheries and Oceans. Vancouver, BC. 173 p.

United States Environmental Protection Agency (US EPA). 1995. Final national pollution discharge elimination system stormwater multi-sector general permit for industrial facilities. Federal Register 60 (189). 50834-51319.

WDOE. 1990. Stormwater best management practices - draft. Washington State Department of Ecology. Olympia, WA, USA. WDOE. 1995. Best management practices to prevent stormwater pollution at logyard and dryland sorts. Washington State Department of Ecology Olympia, WA, USA. Publication \# 95-53.

WDOE. 2000. The Washington State Department of Ecology home page: http://www.wa.gov/ecology/ 